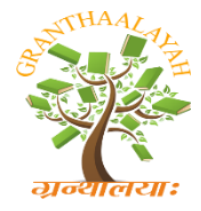

INTERNATIONAL JOURNAL OF RESEARCH GRANTHAALAYAH A knowledge Repository

Social

\title{
QUALITY OF INSTRUCTION IN UP COMING UNIVERSITIES IN THE CASE OF RONGO UNIVERSITY, KENYA
}

\author{
Mr. Ouma Omito *1 \\ ${ }^{1} \mathrm{PhD}$ Student of Educational, Communication and Technology in the Department of Curriculum \\ Instruction and Media at Rongo University, Kenya
}

\begin{abstract}
The study aimed at establishing the quality of instruction to Rongo University students with the aim of producing productive university graduates in all sectors of the world's economy. To achieve this, the researcher formulated one specific objective: to investigate the quality of instruction offered to students by Rongo University's lecturers. The study used survey design with wellconstructed questionnaires. The target population was 30 regular students of Bachelor of Education (Arts) who were training to be business studies teachers in secondary schools in Kenya. A sample size of 28 respondents was reached at by the use of Krajcie and Morgan (1970) table. Simple random sampling was used to pick the respondents. Descriptive statistics such as frequencies and percentages were used to analyze data. The study found that teaching in upcoming universities lacked follow ups, right technology and adequate assignments to students. The study also found that Rongo University was not doing enough to migrate into the digital space since the main method of instruction was face to face and at the same time the available university library did not cater fully for the library needs of students who were outside the main campus. The respondents for this study who were studying outside the main campus relied on internet from their mobile phones as the main source of their reading materials. The study recommended robust reforms that could bring in quality to the ever escalating numbers of higher learning institutions in the world.
\end{abstract}

Keywords: Instruction; Upcoming Universities; Methods of Instruction; Lecturers.

Cite This Article: Mr. Ouma Omito. (2018). "QUALITY OF INSTRUCTION IN UP COMING UNIVERSITIES IN THE CASE OF RONGO UNIVERSITY, KENYA.” International Journal of Research - Granthaalayah, 6(6), 81-87. 10.29121/granthaalayah.v6.i6.2018.1338.

\section{Introduction}

\subsection{Background to the Study}

Worldwide demand for higher education is expected to grow exponentially from 100 million students currently to over 250 million by 2025 but the quality of graduates from higher education was of primary concern in the whole world (European Union, 2014). People regarded the products of universities as highly trained professionals to the extent that they were entrusted with the world's economy as managers, creators and advisors on all front of the economy (Zhang \& An, 
2010).But with the increasing numbers of students seeking places in public universities, the question of quality therefore remained critical and needed urgent attention (Martin, 2018).

The reason could be that universities were expected to be accountable to the general public and major stakeholders on a transformation agenda which was basically dependent on the quality of their graduates (Gudo, Olel \& Oanda, 2011). Instruction was viewed as teaching or lecturing or giving tutorials that was aimed at imparting knowledge or information to learners. It also involved opening up the learners' mind, giving orders and directions to learners. In Africa, the demand for university education has significantly increased and institutions continue to swell (Martin, 2018). Many secondary school graduates and the working class look for opportunities to pursue university education. And as a result, many African governments have persistently been looking for several alternatives to help accommodate the ever rising number of students qualified to join universities (European Union, 2014). One option was to expand university education by allowing the existing universities to setting up one or more constituent colleges to absorb more and more students. These constituent colleges were later declared independent universities. But despite this significant growth in African universities in recent years, keeping pace with the changing international and domestic contexts is a difficult task (British Council, 2015).

The brain drain syndrome has affected African universities in terms of migration of well and highly trained professionals from the continent. The brain drain phenomenon refers to the alarming exodus of human capital from one location to another. As a result, many African universities have been left with young, inexperienced and insufficiently trained staff who may not give quality education to university students (Mbirithi, 2013).

Rongo University which formed the basis of this study was a constituent college of Moi University in Kenya. It fully became a semi-autonomous institution of higher learning in 2013. Rongo University in consultation with Moi University has the power to hire its own staff, admit students but it still lacked the mandate to offer its own courses and graduate students. It therefore taught only the courses approved by Moi University since the college still lacked legal instruments (charter) to operate on its own. The university college had started receiving both government sponsored and privately sponsored students with the majority of the teaching staff being part timers. Rongo University finally received its charter in 2016 (Standard Digital, 2016) but still depended on Moi University courses.

\subsection{Statement of the Problem}

Based on the information given under the background of this study, Rongo University College fell under upcoming universities in developing countries in the world. It was registered and as well recognized by the Government of Kenya to teach university courses. Teaching in general required the use or intervention of university lecturers, but the question was: Were Rongo University's lecturers offering quality teaching to Rongo University's students?

\subsection{Objective of the Study}

The objective of this study was to investigate the quality of instruction offered to students by Rongo University's lecturers. 


\section{Literature Review}

According to Kandiko and Mawer (2013), quality in education meant getting value out of money used in shaping students' career and experience. Therefore, in the context of the sustained growth and diversification of higher education systems in world, stakeholders in education are increasingly concerned about the quality of programs offered to students (European Union, 2014). As a result, there is an increase in public quality assessments and international comparisons of higher education institutions, not only within the higher education sector but in the general media (Great batch \& Holland, 2016). However, evaluation of techniques employed by most universities tends to overemphasize on research, and using research performance as a yardstick of an institution's value. At times these assessment criteria fail to address the quality of teaching which may be complex and difficult (OECD, 2008).

As knowledge and technology evolve, materials from the traditional sources of information and textbooks used for teaching and learning in higher institutions of learning become obsolete in a shorter time. Apparently it was consequently becoming difficult and expensive to adopt them to the specific learning contexts (Gung \& Ricketts, 2006). This was because information technologies had the ability to distribute messages that we usually refer to as media (Reddy \& Manjulika, 2002)

In Kenya, a study was conducted to establish lecturer's commitment to delivery of course contents to university students. A sample of 130 active lecturers participated in this research. Primary data was collected through self-administered questionnaires. It was established that part time lecturers were not satisfied with their jobs and therefore were not adequately motivated, and hence lacked commitment in their work. This negatively impacted on their service delivery. According to this research, quality was seen to be seriously compromised. In that study, only $18 \%$ which was the minority of the respondents admitted to have been sufficiently prepared for the classes, while most of them (42\%) said they were fairly prepared. The others $(22 \%)$ were not prepared for classes they taught. On availability of lecturers for consultations, it was found that $75 \%$ of the lecturers were not available for the consultations and only $20 \%$ said they were occasionally available. Only $5 \%$ of the lecturers indicated that they were available for further consultations (Kyule, Kangu, Wambua, Mutinda \& Kamau, 2013). Keegan (1996) on the other hand emphasized the need to democratize education whereby even the learners had a say in the teaching and learning process. Learners were expected to take control of their learning process through distance learning while the role of teachers should remain facilitators of learning.

Obwogi (2011) in his doctoral research based on the factors affecting the quality of teaching in Kenya found that there was a mismatch between resource allocation by the Government of Kenya and growth in student population. The staff capacity constraints in both the established universities and the constituent colleges continued to be felt. Teaching facilities were getting overstretched thus reducing quality of teaching at universities in Kenya. He also noted that contribution of university staff to society in terms of research and technology transfer was demeaning and that the university teaching staffs were not adequately facilitated in research and publications.

In support of quality teaching at the university level, OCDE (2008) says quality teaching must be thought of dynamically, in light of contextual shifts in the higher education environment. Studies were becoming internationalized and higher education being tasked to contribute to new areas of 
the economy (Kandiko \& Mawer, 2013) in order to produce an appropriately skilled workforce that needed to meet the challenges of the 21 st century. Lecturers on the other hand were expected to be master teachers. Master teachers were those teachers whose classrooms would make the highest gains on achievement tests in which Rosaline (2012) asserted that there were teaching principles that master teachers needed to follow for good performance. They must check on the students' understanding before, during and after instruction:

- A lesson should begin with a short review of the previous lesson followed by presentation of new material in small steps with student practice after each step.

- At the end of every lesson the master teacher is expected to check on the student understanding.

\section{Methodology}

\subsection{Research Design}

The research design used in this study was survey: A survey is an attempt to collect data from members of a population in order to determine the current status of that population with respect to one or more variables (Mugenda \& Mugenda, 2003). The survey design was suitable because it was characterized by a systematic collection of data from members of a given population.

\subsection{Target Population}

Target population is defined as all the number of a real or hypothetical set of people, events of objects to which a researcher generalizes the results of the research study (Borg \& Gall, 1998). The target population for this study consisted of 30 third year regular students who were studying Bachelor of Education (Arts) degree with one teaching subject being Business Studies. The group under the study was Rongo University education students in Town Campus.

\subsection{Sample Size and Sampling Procedure}

To determine the sample size, both probability and non-probability sampling techniques were used. Non probability sampling was used to pick third year education students of business class at Rongo Town Campus. For an appropriate sample size of business class students, a table provided by Krejcie and Morgan (1970) was used. The table gives the required the sample size for various population sizes. The total number of students in this third year regular business class at the Town Campus was 30. According to the table provided by Krejcie and Morgan (1970), the sample size for this study was 28 students. Since the population was not homogeneous and based on learner characteristics, the researcher used simple random sampling.

\subsection{Research Instruments}

Questionnaires were used for data collection from the respondents on quality of teaching the students were receiving from their lecturers. A questionnaire is a data gathering instrument used when factual information is desired (Best \& Khan, 2003). It was important for this study because the researcher administering the instrument had an opportunity to establish rapport, explain the 
purpose under study, and as well explain the meanings of items that were not clear. The researcher used a closed questionnaire for this research.

\subsection{Instruments Validity and Reliability}

Validity of the instruments was done by two experts based on the outcome of the pilot study. Reliability for quantitative data was done by split half method whereby coefficient of 0.72 was realized from odd and even numbers in the questionnaires for students. To obtain reliability of the whole test, the Spearman Brown Prophecy formulae stated below was applied:

$$
\mathrm{Rx}=2 \mathrm{r} / 1+\mathrm{r} \text { where: }
$$

$\mathrm{R}$ was the reliability coefficient resulting from correlating scores of the odd and even numbered items for part of the test;

\section{And}

Rx was the reliability of the original (whole) test.

\subsection{Data Collection Procedures}

The administration of research data collection instrument was done by the researcher both at the pilot and main study. The main research instrument used for data collection was a questionnaire which the researcher administered during the residential session for Bachelor of Education (Arts) students in Rongo Town, Kenya. Research permission was granted by the dean, School of Education, Rongo University. All respondents were assured of confidentiality and security.

\subsection{Data Analysis Techniques}

The researcher used descriptive statistical methods to analyze the collected data. This included quantitative techniques such as frequencies and percentages. Analysis of data was done on each question asked.

\section{Results and Discussions}

The respondents who were third year students were asked to choose on the main instructional method used by lecturers to teach them. The question asked was: What is the main instruction used by your lecturers to teach courses? All respondents, $28(100 \%)$, were taught face to face. None of the respondents was taught using other methods of teaching such as radio, internet, television and course modules. This implied that the upcoming universities either still lacked the capacity to offer options to students for other methods of teaching or these universities were slow to take up the new and integrated methods of teaching that are now practiced in most developed countries in the world. In concurrence, Reddy and Manjulika (2002) proposed that teaching and learning was more effective when a variety media and technologies were in use.

The respondents were also asked to rate the method of instruction used by lecturers as very effective, effective and not effective. The results were: The majority of the respondents, 14(50\%) rated their instruction very effective, $12(43 \%)$ of the respondents rated instruction as effective and 
$2(7 \%)$ rated instruction not effective. The results suggested that majority of students had no problem with the kind and quality of teaching offered by face to face lecturers at Rondo University. It meant that universities had a criterion of selecting good lecturers and as well were committed to scholarly excellence. In support, Rosaline (2012) observed that there were teaching principles that master teachers needed to follow for good performance.

When respondents were asked to state their main source of study materials for learning, 14(50\%) of the respondents were using internet, 11(39\%) of the respondents were using textbooks and $3(11 \%)$ were relying on class notes from lecturers. The result confirmed the findings of Gunga and Ricketts (2006) that there was knowledge explosion and more so print technology was rapidly being overtaken by the World Wide Web. There was need for upcoming universities in Africa to embrace technology and improve on content access.

Lastly students were asked whether they were receiving feedback from tutors or not, majority $9(32 \%)$ of the respondents said that they were not receiving feedbacks from assignments regularly, $5(18 \%)$ respondents agreed that they were receiving regular feedbacks from assignments as $6(21 \%)$ insisted that they were not receiving feedbacks from assignments at all. The results in general reflected that there was need for lecturers to improve on engagement with students and make follow ups where necessary. The universities on the other hand should improve on supervision of lecturers and constantly dialogue with students to identify areas of weaknesses and make appropriate corrections to improve on course delivery. It was also discovered from the majority of the students, $16(57 \%)$, that syllabus coverage needed more time to be completed. This definitely meant that syllabus coverage in higher learning institutions was worrying and universities should needed to find a way of addressing the same because it could be the source of low quality education and half bake graduates from universities. In his observation, Keegan (1996) advocated for distance learning whereby learners needed to be in full control of their studies and the teachers' role in learning should be reduced to a moderator of learning process.

\section{Conclusion}

It was therefore concluded that the idea of mushrooming universities was good as it helped in the elimination of discrimination in societies whereby only very few people have university degrees but there was need for quality education for prosperity of the whole world. Teachers had to be thoroughly trained on ever changing teaching methodologies to achieve this. The education sector in the whole world needed a lot of reforms especially in content delivery areas, curriculum needs and teacher training. Technology to be embraced at all levels of education and where necessary education should be a global affair. Upcoming universities should be regulated and given more attention in terms of investment in technology, learning resources and teacher training.

The study therefore recommended a proper scrutiny of all personnel who aspire to teach at the university as lecturers. Their commitments to work, academic qualifications and response to the needs of students should were crucial. Lastly, in order to retain good lecturers, the study recommended that universities should offer lecturers good salaries and allowances compared to other sectors of the economy. 


\section{References}

[1] Best, J. W., \& Khan, V.J. (2003). Research in Education. South Asia: Pearson Education, Inc.

[2] British Council, (2015). Bridging the gap: enabling effective UK-Africa university partnerships. Retrieved from: www.britishcouncil.org/education/ihe Borg, W.R \&Gall, M.D (1998).Educational Research: An introduction,(4th ed.). New York: Longman publishers.

[3] European Union (2014). Report to the European Commission on New Modes of Learning and Teaching in Higher Education. Retrieved from: ec.europa.eu/dgs/education.../education/.../reports/modernisation-universities_en.pdf Gudo, O. C., Olel, M. A., \& Oanda, O. I. (2011). University Expansion in Kenya and

[4] Issues of Quality Education: Challenges and Opportunities. International Journal of Business and Social Science Vol. 2 No. 20; November 2011203.

[5] Gunga S. \& Ricketts I. (2006). Facing the Challenges of e-learning initiatives in African Universities. British Journal of Educational Technology volume 38, issue 896-906.

[6] Great batch, D., \& Holland, J. (2016). Teaching quality in Higher Education: Literature review and qualitative research. Retrieved from:

https://assets.publishing.service.gov.uk/government/uploads/system/uploads/attachment_data/file/ 524495/he-teaching-quality-literature-review-qualitative-research.pdf Kandiko, C. B., \& Mawer, M. (2013). Student Expectations and Perceptions of Higher Education. London: King's Learning Institute.

[7] Keegan, D. (1996). Foundations of distance education.3rdEd. New York: Rutledge.

[8] Krejcie, V.R. \& Morgan, D. (1970). Determining Sample Size for Research Activities: Educational and Psychological Measurement Vol. 30 No. 3 p.688.

[9] Kyule, A., Kangu, M., Wambua, P., Mutinda, B., \& Kamau, M. (2013). Strategizing on cost:Effect of part time lecturers on university education in Kenya.Prime Journal of Social Science (PJSS),Vol. 3(2), pp. 603-607.

[10] Martin, M. (2018). Internal Quality Assurance: Enhancing higher education quality and graduate employability. Retrieved from: http://unesdoc.unesco.org/images/0026/002613/261356e.pdf.

[11] Mbirithi, D. M. (2013). Management Challenges Facing Kenya's Public Universities and Implications for the Quality of Education. Unpublished $\mathrm{PhD}$ theses, Kenyatta University.

[12] Mugenda,M.O., \&Mugenda,G.A.(2003).Research Methods, Quantitative

And Qualitative approaches. Acts Press, Nairobi.

[13] Obwogi, J. (2011). Factors That Affect Quality of Teaching Staff in Universities in Kenya. Unpublished Theses. JomoKenyattaUniversity of Agriculture and Technology, Kenya.

[14] OECD, (2008). Learning our lesson: Review of quality teaching in higher education.

[15] Retrieve from: http://www.oecd.org/edu/imhe/qualityteaching Reddy, V., \&Manjulika, S. (2002). Towards Virtualization: Open and Distance Learning.

[16] India: Viroid Vasishtha Roseshine, B. (2012). Principles of Instruction. Research-based strategies that all teachers should follow. Received from: https://www.aft.org/sites/default/files/periodicals/Rosenshine.pdf.

[17] Standard Digital (2016). These are the seven universities to be awarded charters by President Uhuru. Retrieved from: https://www.standardmedia.co.ke/ureport/story/2000218608/these-arethe-seven-universities-to-be-awarded-charters-by-president-uhuru.

[18] Zhang, S., \& An, N. (2010). Analysis on the Concepts and Theories of the Quality of Graduate Education. Asian Social Science, 6(12), 86.

\footnotetext{
*Corresponding author.

E-mail address: oumaomito@yahoo.com
} 